\title{
Urban expansion and environmental risk in the São Paulo Metropolitan Area
}

\author{
Andrea Ferraz Young* \\ State University of Campinas, Cidade Universitária 'Zeferino Vaz', Campinas Sao Paulo 13083-970, Brazil
}

\begin{abstract}
In this study, we simulated the expansion of the São Paulo Metropolitan Area (SPMA) - the largest metropolitan area in Brazil - by the year 2030 using the Dinamica EGO software with data extracted from Landsat TM 7 (orbit point 219076 , resolution $30 \times 30 \mathrm{~m}$ ). Based on the urban area in 2008, we used an urban growth scenario to analyze urban expansion up to 2030. Subsequently, we used ArcGIS to integrate the spatial information, combining layers to create risk maps. In this case, environmental risk factors, along with flood and landslide probabilities, were considered in order to identify high-risk areas. By 2030, the urban area was projected to increase by approximately $38.7 \%$, and to cover $3250 \mathrm{~km}^{2}$. With this growth, $807 \mathrm{~km}^{2}$ of the region (and $\sim 4.27 \%$ of urban expansion areas) will be in flood risk zones.
\end{abstract}

KEY WORDS: Climate change $\cdot$ Disasters $\cdot$ Intense precipitation $\cdot$ Flood $\cdot$ Landslide $\cdot$ Urban planning

\section{INTRODUCTION}

In this study, we simulated the expansion of the São Paulo Metropolitan Area (SPMA) by the year 2030 with data extracted from Landsat TM 7, (orbit point 219076 , resolution $30 \times 30 \mathrm{~m})$. Then, based on the urban area in 2008, we constructed an urban growth scenario to analyse the change in 2030. In this case, environmental risk factors and threats for flooding and landslide were considered in order to identify the areas susceptible to high risk.

Climate change is expected to increase the risks of flooding and landslides in the SPMA, which are associated with extreme events like storms and heavy rainfall, as well as with the urbanization process (that causes soil compaction). The SPMA has been undergoing an intense growth, with distinct stages in the urbanization process. The challenge is to understand the main factors that are connected to the processes of spatial expansion and climate change that are taking place in the SPMA.

According to Carlos (2004), the clearest change is related to the displacement of São Paulo's industries to its peripheral areas, which has been observed in other areas around the world and is caused by the changes that have occurred in the production process and as a condition for the businesses to remain competitive, forcing companies to modernize and reduce operating costs. Lower production costs are difficult to attain in densely built-up and extremely specialized metropolitan regions such as São Paulo, where the price of urban land is high compared to the surrounding regions.

The demand for land in the outskirts of the cities that comprise the SPMA is a cause for concern because of the lack of suitable building land, and because soil water capacity is limited by environmental conditions such as topography (slope) and water supply reservoirs. Fast, visible and critical changes in land use and settlement have been taking place at a remarkable and unprecedented pace, reshaping the landscape and affecting the environment. Ecological criteria are not taken into account in urban planning, and legal definitions are often ignored, thus magnifying the potential environmental risks (Ross 2004).

The cities of the SPMA are expanding, and the improved road system is encouraging building be- 
tween the suburbs and towns, reducing the distance between them. This expansion is in progress throughout the SPMA, spurred largely by labour, education, housing and consumption (Bógus \& Pasternak 2009). Oliveira (2004) showed that these processes underway in the metropolitan area have led to the disappearance of immense rural areas that were part of what is now the SPMA as recently as 50 yr ago. Rural areas were turned into legal urban development projects or illegal squatter settlements. The so-called 'green belt,' which had been envisioned to surround the metropolitan area, was occupied due to the eagerness to appropriate income from land use.

For example, in the case of the land allotments for the low-income population, such as those in both the Guarapiranga and Billings watersheds (southern region), developers have broken the water source protection laws (Reydon 2005), splitting up the land without considering the slope of the terrain, its proximity to water bodies, and the existing vegetation. According to the Socio-Environmental Institute (ISA), more than half of the Guarapiranga watershed had been altered by human activities by 2003. Part of this change $(16 \%)$ was related to land use, while the remainder $(34 \%)$ was due to miscellaneous uses such as agriculture and mining. The region has suffered over the past few years from the consequences of an accelerated process of illegal occupation, with replacement of Atlantic forest by urban settlements (ISA 2003).

It is estimated that the urban growth in the Billings watershed was $31.7 \%$ between 1989 and 1999. More than $45 \%$ of settlement recorded in 5 municipalities of the region took place in areas where there were serious or severe restrictions on occupation, such as hillsides, flood areas or lowlands. The population living in slums was estimated at $161000(\sim 19 \%$ of the total) and only $11.8 \%$ of urban expansion occurred in areas deemed as suitable for construction or subdivision into lots (ISA 2003).

Trespass and uncontrolled settlement of land protected by the Water Source Protection Act represents one of the most serious problems in the SPMA, and also affects the Cantareira Mountain Range (to the North) and the Ribeirão dos Campos and Ponte Nova reservoirs, in the municipality of Salesopolis (to the East). The illegal squatter settlements are devoid of any type of infrastructure, such as sewage disposal and treatment networks, running water or urban drainage systems. The vegetation is frequently removed, and soil compaction, due to increased urbanization, exceeds the tolerance limits of the natural system. Natural drainage is seriously impeded, be- cause the rain that would normally seep into the soil has to flow across construction surfaces and through storm-water pipes, increasing the volume and velocity of runoff (Tucci 1995).

This study does not project an increase in inadequate dwellings, but to a significant demand for housing. Future urban expansion in the SPMA is not directly related to extraordinary population growth, but rather is occurring due to growth in production of housing, and also as a result structural changes that have taken place in people's lives, which are much more related to household size and family composition (i.e. a shift away from the nuclear family structure; Givisiez \& Oliveira 2009).

The decrease in the fertility rate that Brazilian society has experienced in recent decades has led to home downsizing; however, the demand for houses and dwellings remains strong. The demand for housing takes into account the need for new residences, a result of the demographic dynamics themselves, but the demographic increase is not necessarily explosive (Givisiez \& de Oliveira 2009). In the case of the SPMA, the population volume resulting from the replacement rate can be considered significant and, thus, so is the demand for new housing.

Givisiez \& de Oliveira (2009) show that the average size of the Brazilian household in 1970 was 5.3 people, and that in $30 \mathrm{yr}$ this number had declined to 3.8 individuals per household. According to the Brazilian Census, there was an average of 3.3 adults per household in 2010 (IBGE 2010). Furthermore, according to Givisiez \& de Oliveira (2009), studies conducted by the Ministry of Cities regarding the demand for housing in Brazil for the period ranging from 1993 to 2023 pointed to a significant housing deficit.

The decline in the average number of adults per household reflects changes in family arrangement that propagate beyond the decrease in the fertility rate: e.g. the age of an individual when first married, mortality rates, trends of adults leaving their parents' homes earlier, divorces and relationship breakups and people living alone, among other factors (Givisiez \& de Oliveira 2009).

These interconnected facts suggest that the SPMA is moving towards a new phase in the urban expansion process, thus experiencing a moment that favours the rethinking of the public policies concerning land use. As seen earlier, the industrial decentralization process also pushes urban expansion to increasingly peripheral territories, causing the region surrounding the city of São Paulo and the ABC (Santo Andre, São Bernardo e São Caetano) to expand at an 
increasing rate, requiring additional infrastructure, access and services that also require space in order to be deployed.

As services specialize and become more sophisticated, more space is consumed because business opportunities grow and diversify, requiring the incorporation of new land. However, in this process of expanding and occupying increasingly distant peripheral areas, urbanization occupies areas with fragile soil, steep slopes, and conditions unsuitable for urbanization, regularly a significant loss of vegetation. For this reason, it is necessary to address problems of illegal settlements, which still persist and could gain new impetus in coming years, because they often do not comply with construction standards and do not respect land use and division rules, thus introducing new risk situations, largely associated with floods and landslides.

\subsection{Urban growth patterns}

According to Bhatta (2009), the urban growth pattern has a direct influence on urban development processes both at the city and neighbourhood levels, but on the other hand, the growth pattern is also affected by land and housing policy, population, economy, and other factors. Remote sensing and GIS techniques were used to analyse and model the urban growth pattern in Kolkata, India.

Pereira et al. (2011) calculated the probability of change between land uses in the Serras do Sudeste and Campanha Meridional (Rio Grande do Sul, Brazil). Through the use of a Markov model, they calculated the probability of a determinate land use (forest) staying the same or moving to another use (cattle) during a period of time. The main results are simulations based on the paradigm of Cellular Automata (CA), in which the forest areas are quantified and spatially distributed until the year 2016 .

Almeida et al. (2012) built up a methodological process for modelling urban land-use change through GIS, remote sensing imagery and Bayesian probabilistic methods. The probabilities were obtained from a CA simulation model (Dinamica EGO) based on stochastic transition algorithms. Different simulation outputs were generated for the city of Bauru (São Paulo) for the period 1988 to 2000.

Merry et al. (2009) implemented complex models involving a huge amount of data and large number of advanced spatial algorithms for the Amazon timber industry on Dinamica EGO. Soares-Filho et al. (2010) ran applications that include modelling tropical de- forestation in the Amazon. Teixeira et al. (2009) used a similar model to study the land use and cover change in the Atlantic forest.

Examples of Dinamica EGO applications include the analysis of land use transitions (Almeida et al. 2012, Godoy \& Soares-Filho 2008); deforestation in the Amazon caused by logging, contributing to forest flammability (Merry et al. 2009); and forest fire risk (analysis of carbon emissions from tropical deforestation and peatland fires) (Silvestrini et al. 2011); as well as the patterns of drought in Mexican forests (Cuevas \& Mas 2008). Furthermore, the application of Dinamica EGO was fundamental in developing the analysis of REDD (Reducing Emissions from Deforestation and Forest Degradation), a mechanism for compensating deforestation reduction in the Brazilian Amazon by payments for tropical forest carbon credits system (Nepstad et al. 2009), and modelling the co-benefits of REDD in Xingu for reducing carbon emissions caused by deforestation (Stickler et al. 2009).

Mas \& Vega (2012) generated land cover projections based on transition matrices in order to produce land cover maps at different dates. Yi et al. (2012) developed dynamic models using Dinamica EGO, with data extracted from SPOT VGT NDVI, in order to understand the process and driving mechanism of land-use change in China in 2020. Maeda et al. (2011) simulated the expansion of agricultural and cattle raising activities within a watershed located in the fringes of the Xingu National Park, Brazilian Amazon. A spatially dynamic model of land cover and land use change was used to provide both past and future scenarios of forest conversion for such rural activities, aiming to identify driving forces of change in the study area.

\section{MATERIALS AND METHODS}

The SPMA is set in a sedimentary basin (Tiete river basin) centered near $23^{\circ} 32^{\prime} \mathrm{S}, 46^{\circ} 38^{\prime} \mathrm{W}$, a low-lying region within the Atlantic Mountain Chain. It occupies $~ 8000 \mathrm{~km}^{2}$ and is surrounded by hills that vary from 650 to $1200 \mathrm{~m}$ in height (above sea level). Its proximity to the ocean influences the atmospheric circulation patterns occuring there. The region is encroaching on the remaining portions of the Atlantic forest biome, which, in Brazil, despite the high levels of devastation, is still home to a significant amount of biological diversity. The vegetation of the region is therefore made up of only fragments of secondary Atlantic forest (known as Mata Atlântica). 
São Paulo is the largest metropolitan area in Brazil, with almost 20 million inhabitants. It is located in São Paulo state (in south-eastern Brazil), $600 \mathrm{~km}$ southwest of Rio de Janeiro and $80 \mathrm{~km}$ inland from the Atlantic Ocean, and has a population density of $\sim 2500$ inhabitants $\mathrm{km}^{-2}$. The population grew by $0.98 \%$ from 2000 to 2010 , due mainly to the difference between births and deaths, in spite of an outflow due to migration (-1.62 per thousand inhabitants; 30300 people $\mathrm{yr}^{-1}$ ) (IBGE 2010).

According to SEADE (2010), the SPMA is also home to the largest employment base (9.7 million workers), with a GDP about $\$ 347$ billion, and a GDP per capita around $\$ 17666$, and with a per capita income of about \$470. São Paulo's largest industries are slightly more diverse than those in other metropolitan areas. Its largest sector, services, makes up $50 \%$ of the economy, and since 1990, São Paulo has seen the largest growth in its information services $(251 \%)$ and business services $(105 \%)$.

We used the Dinamica EGO software to simulate the urban projection of SPMA for the year 2030 with data extracted from Landsat 5 and TM 7 (orbit point 219076 , resolution $30 \times 30 \mathrm{~m}$ ). Then, based on the present situation we assumed one scenario under which we could analyse the urban land use in 2030. Referring to Fig. 1, we see the extent of the expansion in 2001 (in orange) and 2008 (in gray).

First, we used a method of classifying satellite images that involved the identification of urban areas in the image as 'Training Samples' to seed the clustering algorithm in the ENVI 3.6 software. A Maximum Likelihood algorithm was used to categorize each location with the group that it is most similar to. The objective of the image classification was to automatically categorize all pixels in the satellite images into classes. The spectral pattern or signature of surface materials determines an assignment to a class, and a numeric description of the spectral attribute of each class is specified. In this case, we considered 3 classes: urbanized, non-urbanized areas and water (i.e. reservoir, rivers and channels).

The second step in the process was based on calculating the cell transitions using the software Dinamica EGO in order to obtain a cross-tabulation map between the initial (2001/2008) and final (2030) landuse map. The Dinamica graphical interface allows the design of a model that performs calculations on various types of data, such as constants, matrices, tables and raster maps. In this way, one can easily set up a model by establishing a sequence of operators involving an ample range of analytical and simulation algorithms. In an attempt to understand the physical growth process, an algorithm was used to express or represent the urban expansion:

$$
A(t)=A_{0}(1+i) t
$$

where $A_{0}$ : initial growth, $A(t)$ : growth after $t$ yr, $i$ : unit growth rate, and $t$ : time measured in yr, i.e. number of yr elapsed.

The respective areas of the years 2001 and 2008 were calculated, as well as the urban growth rate (Table 1), which was determined for the elapsed time period $(7 \mathrm{yr}$ ). To verify the consistency of the data obtained, satellite imagery data were compared to official data published by the São Paulo Metropolitan Planning Company (Empresa Paulista de Planejamento Metropolitana, Emplasa). It is noteworthy that Emplasa used orthorectified aerial photographs at a scale of 1:25000, which afford a superior level of detail as compared to the Landsat imagery (1:250 000). One important aspect is the fact that Emplasa considered a period of $5 \mathrm{yr}$. Considering these factors, there may have been some variations between surveys.

In the sequence, a Markov chain was employed for the estimation of global transition in the case of simulation (urban forecast) through Dinamica EGO. According to Lambin (1994, p. 28), this is a 'mathematical model designed to describe a certain type of process that moves in a sequence of steps through a set of states', whose formula is defined as:

$$
\pi(t+1)=\boldsymbol{P} \pi(t)
$$

where $\pi(t)$ is a column vector, with $n$ elements, that represents the condition of the system at a certain time $t$ (e.g. area percentages for each $\mathrm{n}$ land-use category or state); $\pi(t+1)$ is the vector representing the occupation of $n_{i}$ states at a given future time $t+1$; and $\boldsymbol{P}$ is the transition probability matrix or the table for land-use transition rates.

It is important to highlight that according to Meyn \& Tweedie (2005), the Markov model assumes that transition probabilities do not change over time. It is a mathematical system that undergoes transitions

Table 1. Urban area expansion and annual growth rate for the São Paolo Metropolitan Area (parentheses: year). Data

\begin{tabular}{|c|c|c|c|}
\hline $\begin{array}{l}\text { Initial area } \\
\left(\mathrm{km}^{2}\right)\end{array}$ & $\begin{array}{c}\text { Final } \\
\text { area }\left(\mathrm{km}^{2}\right)\end{array}$ & $\begin{array}{c}\text { Increase in } \\
\text { area }\left(\mathrm{km}^{2}\right)\end{array}$ & $\begin{array}{l}\text { Growth } \\
\text { rate }\end{array}$ \\
\hline \multicolumn{4}{|l|}{ Emplasa } \\
\hline 2193.1 (2002) & 2318.7 (2007) & 125.6 & 0.011 \\
\hline \multicolumn{4}{|l|}{ Satellite image } \\
\hline $1901.8(2001)$ & 2123.4 (2008) & 221.58 & 0.015 \\
\hline
\end{tabular}
source: Landsat satellite (2001/2008) 
Table 2. Criteria used to isolate high risk areas in the São Paolo Metropolitan Area. Criteria were derived from a combination of factors associated with different risks

\begin{tabular}{|lccccc|}
\hline $\begin{array}{l}\text { Land use } \\
\text { (classes) }\end{array}$ & $\begin{array}{c}\text { Patch no. } \\
\text { (1st step) }\end{array}$ & $\begin{array}{c}\text { Criteria } \\
\text { (conjunction of factors) }\end{array}$ & $\begin{array}{c}\text { Risk } \\
\text { (classes) }\end{array}$ & $\begin{array}{c}\text { Patch no. } \\
\text { (2nd step) }\end{array}$ & Classification \\
\hline Water & 0 & Water + non compacteness & Middle & 0 & $\begin{array}{c}\text { Non represented } \\
\text { Non represented } \\
\text { Non urbanized }\end{array}$ \\
Urbanized & 1 & Non urban + non compacteness & & 0 & High risk \\
Water & 2 & Urban + compacteness & High & 0 & Non represented \\
Non urbanized & 1 & Water + non compacteness & Non represented \\
Urbanized & 2 & Urban + non compacteness & & 0 & High risk \\
Water & 0 & Water + non compacteness & Very high & 0 & Non represented \\
Non urbanized & 1 & Non urban + non compacteness & & 0 & Non represented \\
Urbanized & 2 & Urban + compactness & & 1 & High risk \\
\hline
\end{tabular}

from one state to another. The next state depends on the current state and not on the sequence of events that preceded it (Lambin 1994). Moreover, Lambin (1994, p. 32) highlights that 'given its stochastic nature, the Markov chain masks the causative variables; for this reason, it is not an explanatory model and cannot be used to understand the causes and driving factors of land-use transition processes.' Nevertheless, according to Lambin (1994, p. 29, 32) the Markov chain analysis has the great advantage that 'the model parameters are easily estimated' and 'simple trend projection involves no more than matrix multiplication and the only data requirement is the current land-use information'.

Through the Dinamica EGO, we used 2 complementary transition functions: the Expander and the Patcher. The first process, the Expander was dedicated to the expansion of previous patches of a certain class (i.e. urbanized areas). The second process, the Patcher, was applied to generate new patches (a patch is a number varying from 0 to 2 ). The Patcher function searches for cells around a chosen location for a combined transition. This is done electronically, first by electing the core cell of the new patch and then selecting a specific number of cells around the core cell, according to their transition probabilities.

Subsequently, we used ArcGIS to integrate the spatial information, where each theme was linked. By overlaying the spatial information layers, such as hydrography, land use, slope, flooding points, and precipitation, we were able to arrange all the information spatially.

Environmental risk factors and threats for flooding and landslides were considered (through specific criteria), in order to identify the areas susceptible to high risk (Table 2). In other words, since the criteria were based on the objective of identifying high-risk areas, the urbanized areas were considered more representative and significant than the non-urbanized and water areas, due to compacting (soil sealing) and drainage problems without adequate infrastructure (including construction). We then used the ArcGIS 'math' module to perform mathematical operations that allowed us to integrate and analyse the patterns and trends of the region in 2030.

\section{RESULTS}

The results obtained from transition function analysis are presented in Fig. 1. They were central in terms of providing fundamental connections between empirical observation and mathematical expression.

By simulating the expansion in 2030, we found that urban spread will intensify in the peripheral area of the SPMA. The urban expansion trend reveals 2 important aspects: the consolidation of urban space in the city of São Paulo; and the expansion of surrounding areas, which will exert strong pressure on the existing natural resources (e.g. the Serra da Cantareira and Serra do Mar, Billings and Guarapiranga dams).

By 2030 , the urban area will have spread $\sim 38.7 \%$, and will cover $3254 \mathrm{~km}^{2}$. With this growth, the region will have $807 \mathrm{~km}^{2}$ of areas subject to the risk of floods, $\sim 46.1 \%$ increase during the period. The areas at risk are projected to spread towards the water supply sources (Alto Tietê River Basin, in the Eastern Zone; and the Billings and Guarapiranga dams, in the Southern Zone).

The results showed that the areas susceptible to flooding accounted for $23.5 \%$ of urban area in 2008 , and $22.3 \%$ in 2030 . These areas at risk increased $\sim 254 \mathrm{~km}^{2}$ in a total area of $1141 \mathrm{~km}^{2}$.

Likewise, the map showing areas vulnerable to landslides in 2030 (Fig. 3) shows that $\sim 4.27 \%$ of the 




Fig. 1. Urban areas of São Paolo Metropolitan Area (SPMA) in 2001 (orange) and 2008 (gray), and urban expansion in 2030 (red)



Fig. 2. Areas in São Paulo Metropolitan Area vulnerable to floods in 2030 
expansion areas may become new areas at risk. This seemingly small percentage represents a relative increase upwards of $200 \%$ in the period, or in other words, the area currently prone to landslides $(0.9 \%)$ could almost triple, from $21.21 \mathrm{~km}^{2}$ in 2008 to $69.88 \mathrm{~km}^{2}$ in 2030 .

These areas are located mainly in the Serra da Cantareira, Serra do Mar and in São Lourenço da Serra, which are not yet fully occupied since they are considered Areas of Environmental Protection. The areas consist of land located on steep slopes that contain alluvial deposits, and therefore require special care in the implementation of any kind of urban settlement; they are also unstable due to a combination of upstream erosion greater river energy and increased surface runoff.

\section{CONCLUSION}

The combination of Dinamica EGO's transition function, GIS and remote sensing techniques provides a powerful tool with respect to the generation and evolution of spatial patterns of change. Through the transition function, we performed a simulation of future land use change (2030), utilizing land use maps from 2 different dates (2001 and 2008).
This simulation provides important input to urban planning and broader political analyses, since urban development can increase environmental risk in the SPMA due to local changes in hydrological and hydrometeorological conditions (which increase flood hazard) and landslide vulnerability. It makes clearer the relationship between urban growth, flooding and landslides due to increased impermeability, which is aggravated by rainfall via microclimatic changes.

The land use in the SPMA is diverse (e.g. trade, services, industry, settlements with high standard of wealth); however, the concentration of low-income populations along the Tiete basin, in areas of protection (riverbanks and floodplains) causes concern in view of the precarious housing conditions, obstruction of water bodies and weathering and erosion.

Altogether, urbanization is causing serious changes in the remaining areas of the watershed, stretching into its tributaries and occupying its slopes and headwaters as well. If this process persists through 2030, new areas of risk will appear and vulnerability will increase, with regard to both floods and landslides.

The region of the SPMA where changes are felt most intensely, with $80 \%$ of the already urbanized, is the stretch that includes the Tiete and Pinheiros River basins. These areas are located on the flood plain or stream terraces, where the natural vegeta-

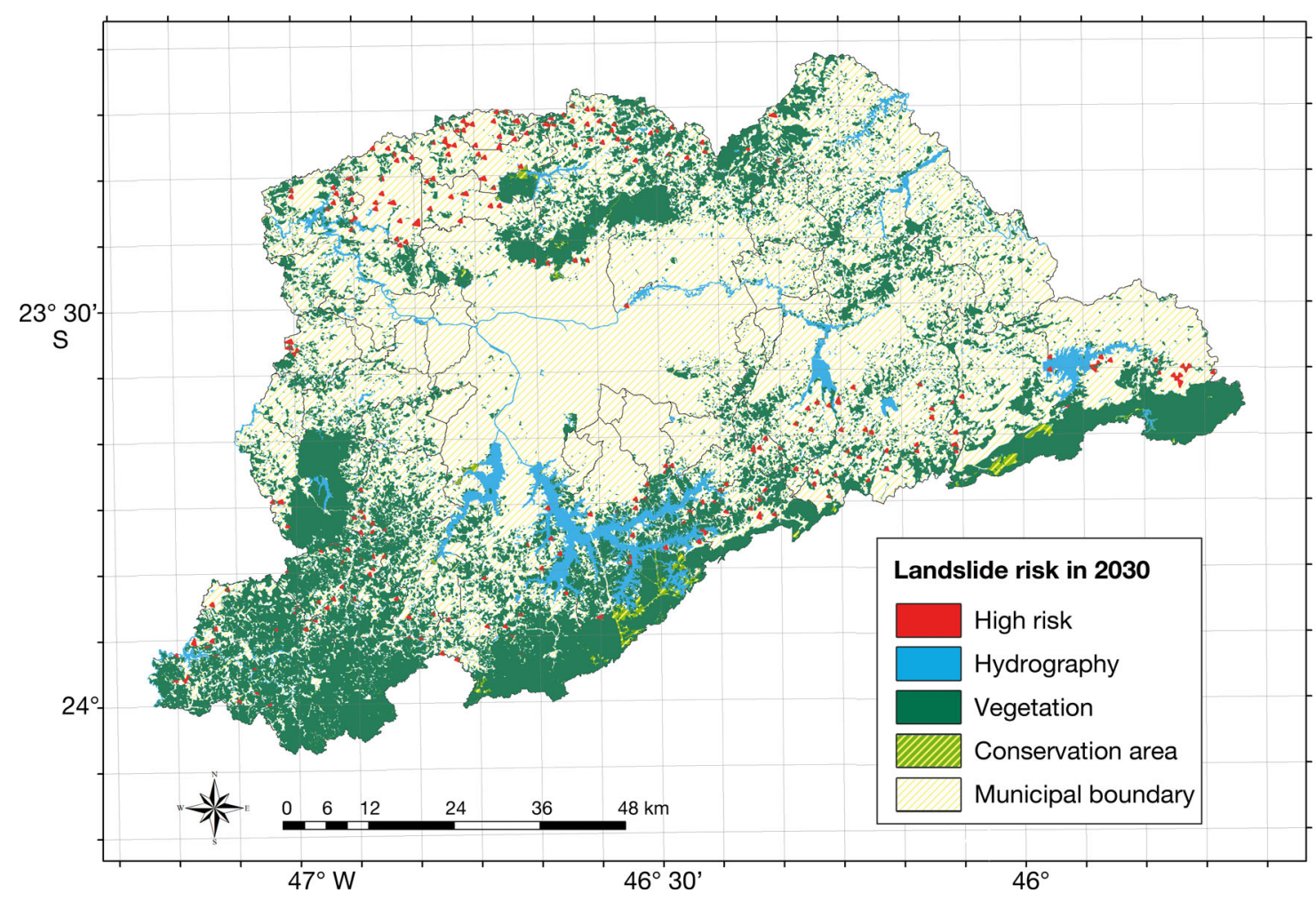

Fig. 3. Areas in São Paulo Metropolitan Area vulnerable to the risk of landslides in 2030 
tion cover was removed and where there was excessive soil surface sealing. These flood plains are already under intense pressure from urban expansion, and by 2030 the phenomenon will have spread through the landscape if effective measures are not implemented to regulate the expansion process. The demand for new housing is crucial for all social classes, and may not be and/or should not be restricted by the housing market.

Acknowledgements. This work was partially funded by the British Embassy in Brazil via the Strategic Programme Fund (SPF) from Foreign and Commonwealth Office, UK, and National Institute of Science and Technology (Brazil) through the study 'Vulnerability of Brazilian Megacities to Climate Change: Metropolitan Areas of São Paulo and Rio de Janeiro'.

\section{LITERATURE CITED}

Almeida CM, Soares-Filho BS, Rodrigues HO (2012) Evolutionary computing and CA models: a genetic algorithm tool to optimize the Bayesian calibration of an urban land use change model. In: Proc Int Symp Cell Automata Modeling Urban Spatial Syst, CAMUSS, Vol 1. University of Coimbra, p 243-255

Bhatta B (2009) Analysis of urban growth pattern using remote sensing and GIS: a case study of Kolkata, India. Int J Remote Sens 30(18, 20):4733-4746

Bógus LMM, Pasternak S (2009) Como anda São Paulo. Letra Capital, Observatório das Metrópoles, São Paolo

Carlos AFA (2004) São Paulo do capital industrial ao capital financeiro. Geografia de São Paulo. A metrópole do séc XXI, Vol. 2. Contexto, São Paulo

Cuevas SG, Mas JF (2008) Land use scenarios: a communication tool with local communities. In: Paegelow M, Camacho Olmedo MT (eds) Modelling environmental cynamics. Springer-Verlag, Wiesbaden

Givisiez GHN, de Oliveira EL (2009) Household size and demographic dividend in Brazilian housing market. XXVI IUSSP Int Popul Conf, Marrakesh

Godoy M, Soares-Filho BS (2008) Modelling intra-urban dynamics in the Savassi neighbourhood, Belo Horizonte city, Brazil. In: Paegelow M, Camacho Olmedo MT (eds) Modelling environmental dynamics. SpringerVerlag, Wiesbaden, p 319-338

IBGE (Instituto Brasileiro de Geografia e Estatística) (2010) Primeiros resultados definitivos do Censo 2010. http:// site-antigo.socioambiental.org/prg/man.shtm

ISA (Instituto Socio Ambiental) (2003) Diagnóstico socioambiental. www.ibge.gov.br/home/estatistica/populacao/ censo2010/primeiros_resultados/default_primeiros_ resultados.shtm

Lambin EF (1994) Modelling deforestation process: a review. TREES Ser B, Res Rep 1. European Commission, Brussels

Maeda EE, Almeida CM, Ximenes AC, Formaggio AR, Shimabukuro YE, Pellikka P (2011) Dynamic modeling of forest conversion: simulation of past and future scenarios

Editorial responsibility: Helmut Mayer,

Freiburg, Germany of rural activities expansion in the fringes of the Xingu National Park, Brazilian Amazon. Int J Appl Earth Obs Geoinf 13(Issue 3):435-446

Mas JF, Vega E (2012) Assessing yearly transition probability matrix for land use/land cover dynamics. Proc 10th Int Symp Accuracy Assess Nat Resour Environ Sci

Merry F, Soares-Filho BS, Nepstad D, Aamacher G, Rodrigues $H$ (2009) Balancing conservation and economic sustainability: the future of the Amazon timber industry. Environ Manag 44:395-407

Meyn S, Tweedie RL (2005) Markov chains and stochastic stability, 2nd edn. Cambridge University Press, Cambridge

Nepstad D, Soares-Filho BS, Merry F, Lima A and others (2009) The end of deforestation in the Brazilian Amazon. Science 326:1350-1351

Oliveira AU (2004) São Paulo: dos bairros e subúrbios rurais as bolsas de mercadorias e de futuro. Geografia de São Paulo. A metrópole do séc, XXI, Vol 2. Contexto, São Paulo

Pereira RS, Benedetti ACP, de Almeida CM (2011) Dynamic modeling for changes simulations in the forest cover in Rio Grande do Sul State, Brazil. Bridging the Gap between Cultures. FIG Working Week 18-22 May 2011, Marrakesh

Reydon B P (2005) O mercado de terras informal nas áreas de mananciais. Facilitating negotiations over land and water conflicts in Latin-American peri-urban upstream catchment: combining agent-based modelling with role playing game. FAPESP Rep. PROJECT NEGOWAT, Campinas

Ross JL (2004). São Paulo: a cidade e as águas. Geografia de São Paulo. A metrópole do séc, XXI, Vol 2. Contexto, São Paulo

SEADE (Fundação Sistema Estadual de Análise de Dados) (2010) Perfil regional: Região Metropolitana de São Paulo, available at: www.seade.gov.br/produtos/perfil_ regional/index.php

Silvestrini RA, Soares-Filho BS, Nepstad D, Coe M, Rodrigues HO, Assunção R (2011) Simulating fire regimes in the Amazon in response to climate change and deforestation. Ecol Appl 21:1573-1590

Soares-Filho BS, Dietzch L, Moutinho P, Suarez AF, Rodrigues $H$ (2010) Protected areas helping to reduce carbon emissions in Brazil. In: Arguments for protected areas: multiple benefits for conservation and use. EarthScan, London, p 1-268

- Stickler C, Nepstad D, Coe M, McGrath D, Rodrigues H, Dabidson E, Soares-Filho B (2009) The potential ecological costs and co-benefits of REDD: a critical review and case study. Glob Change Biol 15:2803-2824

Teixeira AM, Soares-Filho BS, Freitas S, Metzger JPW (2009) Modeling landscape dynamics in the Atlantic Rainforest domain: implications for conservation. For Ecol Manag 257:1219-1230

Tucci CEM (1995) Inundações urbanas. In: Tucci CEM, Porto RL, Barros MT (eds) Drenagem urbana. Universidade do Rio Grande do Sul

Yi W, Gao Z, Li Z, Chen M (2012) Land-use and land-cover sceneries in China: an application of Dinamica EGO model. Proc SPIE: Remote sensing and modeling of ecosystems for sustainability IX. SPIE, San Diego, CA

Submitted: August 30, 2012; Accepted: April 11, 2013

Proofs received from author(s): July 23, 2013 